\title{
Correction to: Distribution and Abundance of Coastal Elasmobranchs in Tenerife (Canary Islands, NE Atlantic Ocean) with Emphasis on the Bull Ray, Aetomylaeus bovinus
}

\author{
Jorge Moreno $^{1} \cdot$ Silvio E. Solleleit-Ferreira ${ }^{2} \cdot$ R. Riera ${ }^{3,4}$
}

Published online: 11 October 2021

(c) Springer Nature Switzerland AG 2021

\section{Correction to: Thalassas: An International Journal of Marine Sciences https://doi.org/10.1007/s41208-021-00316-1}

The original article has been corrected. The correct name of the first author should be "Jorge Moreno", instead of "Jorge Manuel Moreno Mendoza".
Publisher's Note Springer Nature remains neutral with regard to jurisdictional claims in published maps and institutional affiliations.

The original article can be found online at https://doi.org/10.1007/ s41208-021-00316-1.

Jorge Moreno

jorgemanuel.morenomendoza@imbrsea.eu

1 International Master of Marine Biological Resources (IMBRSea), Ghent University, Ghent, Belgium

2 Institute of Marine Research (IMAR), University of the Azores, Horta, Portugal

3 Departamento de Ecología, Facultad de Ciencias, Universidad Católica de La Santísima, Conceptión, Conceptión, Chile

4 IU-ECOAQUA, Grupo en Biodiversidad Y Conservación, Departamento de Biología, Universidad de Las Palmas de Gran Canaria, Las Palmas, España 